\title{
Activity of Paraoxonase 1 and Lipid Profile in Healthy Children
}

\author{
K. SUMEGOVÁ ${ }^{1}$, Z. NAGYOVÁ ${ }^{2}$, I. WACZULÍKOVÁ ${ }^{3}$, I. ŽITŇANOVÁ ${ }^{1}$, \\ Z. ĎURAČKOVÁ ${ }^{1}$
}

${ }^{1}$ Department of Medical Chemistry, Biochemistry and Clinical Biochemistry, School of Medicine, Comenius University, Bratislava, ${ }^{2}$ Paediatric Department, Non-state Medical Facility, Dunajská

Streda, Slovakia, ${ }^{3}$ Department of Nuclear Physics and Biophysics, Division of Biomedical Physics, Faculty of Mathematics, Physics and Informatics, Comenius University, Bratislava, Slovakia.

\begin{abstract}
Summary
Paraoxonase 1 (PON1) seems to have a relevant role in detoxifying processes and in atherosclerosis. The aim of this study was to determine PON1 activity, the total antioxidant capacity, as well as entire lipid profile in children for screening of possible risk of atherosclerosis development. Serum PON1 arylesterase/paraoxonase activities were determined spectrophotometrically. The total antioxidant capacity of the serum was measured by TEAC method. Parameters of lipid profile were analyzed by routine laboratory methods. It has been shown that PON1 arylesterase/ paraoxonase activities were very similar to values found in adults. In children, no significant correlation between PON1 arylesterase activity and HDL was observed. PON1 paraoxonase activity correlated only with atherogenic index. PON1 arylesterase activity was significantly higher in girls than in boys. The antioxidant capacity was inversely related to the body mass index. In this study, PON1 activity was determined in healthy children aged 11 to 12 years and we found a similarity in PON1 activities of children and adults. Moreover, the results of our study support the hypothesis that higher body weight of children may contribute to a greater risk for development of atherosclerosis in which oxidative stress plays a role.
\end{abstract}

\section{Key words}

Atherosclerosis $\bullet \mathrm{HDL} \bullet$ Lipid peroxides $\bullet$ Paraoxonase $1 \bullet$ TEAC

\section{Introduction}

The association between organophosphate pesticides, paraoxonase 1 (PON1) and atherosclerosis is not manifest in a majority of people. Organophosphate pesticides are sulphur derivates widely used in agriculture. These nontoxic compounds are transformed in the liver to toxic oxon forms that are further detoxified by several enzymes such as PON1, transferase or monooxygenase. In mammals, any oxon form that escapes hepatic detoxification can be hydrolyzed in the blood by serum paraoxonase before it reaches the brain (Mackness et al. 1998).

PON1 is a dimmer with molecular weight in the range of 43000-45000. Its gene is located on the long arm of chromosome 7 (Mackness et al. 2002a,b) and was 
detected besides the serum and liver also in other tissues such as kidneys or small intestine. Major part of this enzyme in the serum is associated with HDL particles, but a low level of PON1 was also observed in VLDL and postprandial chylomicrons (Aviram and Rosenblat 2004, Fuhrman et al. 2005). No PON1 is bound to LDL particles (James and Deakin 2004), although PON1 plays a key role in LDL protection. It is believed that PON1 has two active sites because it acts as a detoxifying enzyme hydrolyzing oxygen analogs of several organophosphorus insecticides as well as nerve agents but also as an antiatherogenic enzyme, capable of attenuating plaque formation. This antiatherogenicity comes from its ability to protect lipoprotein particles from free radical oxidation because it can hydrolyze oxidized cholesteryl esters, phosphatidylcholine core aldehydes, and degrade hydrogen peroxide (Aviram et al. 2000, Ahmed et al. 2001, Aviram and Rosenblat 2004). Concerning the physiological substrate for PON1, this question is still open.

The beneficial role of this enzyme on atherosclerosis has been supported by several authors directly or indirectly showing that PON1 reduces oxidative stress. Shih et al. (2000) observed in apolipoprotein E/PON1 double mutant mice increased lipoprotein oxidation in comparison to apolipoprotein Emutant controls. In addition, decreased activity of PON1 and its other isoform has been reported by $25-45 \%$ in apolipoprotein E-deficient mice vs. controls (Aviram and Rosenblat 2004). Further studies have demonstrated that PON1 activity is reduced in human subjects prone to develop atherosclerosis such as in individuals with diabetes mellitus type 1 and 2, or hypercholesterolemia (Mackness et al. 2000, 2001, 2002a,b).

Taken together, PON1 seems to be responsible for inhibition of oxidative processes. This finding indicates that the determination of PON1 activity could already be of benefit for children in order to protect them from atherosclerosis in the future.

Because it is known that every fourth child in Slovakia has high cholesterol levels, the purpose of our study was to determine PON1 activity, lipid profile and total antioxidant capacity in children aged 11 and 12 years.

\section{Methods}

\section{Patients and sample preparation}

Seventy healthy children (mean age $11.62 \pm 0.06$; range 11-12 years) joined this study after written consent of their parents. Blood samples were collected from veins into serum commercial tubes (S-Monovette ${ }^{\circledR}$, Sarstedt). After centrifugation (1200 xg, $10 \mathrm{~min}$ ), serum was frozen and kept at $-80{ }^{\circ} \mathrm{C}$ until use.

\section{Determination of parameters of lipid metabolism}

Serum total cholesterol, HDL-cholesterol and triacylglycerols (TAG) were analyzed by routine biochemical procedures on Hitachi 721 (Roche, Switzerland). LDL-cholesterol was calculated according to the formula of Friedewald et al. (1972).

\section{Determination of PON1 arylesterase activity}

PON1 arylesterase activity in serum was determined spectrophotometrically by using synthetic substrate - phenylacetate (Sigma, USA) according to Gan et al. (1991) with a slight modification. After adding $100 \mu \mathrm{l}$ of $10 \mathrm{mmol} / \mathrm{l}$ substrate solution to assay mixture containing $5 \mu \mathrm{l}$ serum and $1 \mathrm{mmol} / \mathrm{CaCl}_{2}$ (Sigma, USA) in $50 \mathrm{mmol} / \mathrm{l}$ Tris buffer $\mathrm{pH} 8$ (AppliChem, Biochemica, Germany), production of phenol was detected after $2 \mathrm{~min}$ at $270 \mathrm{~nm}$ (Biochrom 4060, Cambridge, UK). PON1 arylesterase activity was determined in triplicate and all results are presented in $\mu \mathrm{mol}$ per min per ml. Mean intraand inter-assay coefficients of variation for this analysis were $4.2 \%$ and $7.1 \%$, respectively.

\section{Determination of PON1 paraoxonase activity}

PON1 paraoxonase activity in serum was measured spectrophotometrically at $412 \mathrm{~nm}$ according to Beltowski et al. (2002) with some modifications. Determination of PON1 paraoxonase activity was performed by using paraoxon (Sigma, USA). Reaction mixture contained $10 \mu \mathrm{l}$ serum and $1 \mathrm{mmol} / \mathrm{l} \mathrm{CaCl}_{2}$ (Sigma, USA) in $20 \mathrm{mmol} / \mathrm{l}$ Tris buffer, $\mathrm{pH} 8$ (AppliChem, Biochemica, Germany). The reaction was initiated by adding $3.27 \mathrm{mmol} / \mathrm{l}$ paraoxon to assay mixture. The production of p-nitrophenol was detected after $3 \mathrm{~min}$ by Biochrom 4060 spectrophotometer (Cambridge, UK). PON1 paraoxonase activity was monitored in triplicate and all results are presented in nmol per min per ml. Intra- and inter-assay coefficients of variation were $13.3 \%$ and $10.9 \%$.

\section{TEAC (trolox equivalent antioxidant capacity) assay}

The antioxidant capacity of serum was assessed by TEAC assay using 2,2'-azino-bis(3-ethylbenzothiazoline-6-sulfonic acid)diammonium salt tablets 
(ABTS) (Sigma, USA) according to Re et al. (1999). The method is based on the production of blue-green $\mathrm{ABTS}^{+}$ radical cation formed by potassium persulfate (Lachema, Czech republic) that was subsequently reduced in the presence of blood antioxidants into colorless form. ABTS $^{+}$radical solution was prepared $12-16 \mathrm{~h}$ before each assay. The reaction mixture was prepared with a slight modification because $\mathrm{ABTS}^{+}$radical solution was diluted with water instead of phosphate buffered saline solution. Reaction was initiated by adding $10 \mu \mathrm{l}$ of sample to the reaction mixture. The reduction of absorbance was read after $10 \mathrm{~min}$ and quantification was performed on the basis of the dose-response curve for reference antioxidant Trolox - a water-soluble form of vitamin E (Sigma, USA). Results are presented in mmol of Trolox per liter. The intraassay coefficient of variation for this analysis was lower than $4.6 \%$.

\section{Statistical analysis}

All results are presented as mean \pm S.E.M. Student's t-test was used for the analysis of data with a Gausian distribution. The data with non-Gausian distribution were compared with Mann-Whitney U-test. $\mathrm{P}<0.05$ value was considered to be statistically significant. The Pearson's product moment and Spearman's correlation coefficients were used to determine the relationships between the studied parameters. Logistic regression analysis was used to determine the odds ratios (OR) with $95 \%$ confidence intervals (CI) between TEAC and BMI, as well as between TEAC and TAG. The correlation analysis was performed by using StatsDirect ${ }^{\circledR}$ 2.3.7 (StatsDirect Sales, Sale, Cheshire M33 3UY, UK).

\section{Results}

Personal and biochemical parameters of children are shown in Table 1. All lipid parameters were in the reference ranges for children determined in our laboratory. Surprisingly, we found out that $24.3 \%$ children from the study group had total cholesterol levels above $4.5 \mathrm{mmol} / 1$. Total cholesterol levels above $4.5 \mathrm{mmol} / \mathrm{l}$ are considered harmful to health for this age group.

The PON1 arylesterase activity was determined towards phenylacetate as a substrate. Serum PON1 arylesterase activity in children was $80.97 \pm 2.10$ $\mu \mathrm{mol} / \mathrm{min} / \mathrm{ml}(\mathrm{n}=63)$ and ranged from 30.88 to 120.50 $\mu \mathrm{mol} / \mathrm{min} / \mathrm{ml}$. This activity was very similar to the mean of PON1 arylesterase activity determined in 30 healthy adults $(86.04 \pm 3.26 \mu \mathrm{mol} / \mathrm{min} / \mathrm{ml})$ with the mean age of 41.3 years (unpublished results).

PON1 arylesterase activity in children was not correlated with any other lipid parameters such as total, LDL- or HDL-cholesterol and TAG (Table 2). The relationship between PON1 arylesterase activity and the total cholesterol/HDL-cholesterol ratio was also nonsignificant.

For determination of PON1 paraoxonase activity, synthetic compound - paraoxon as a substrate was used and the production of p-nitrophenol was detected. Serum PON1 paraoxonase activity in children was $97.55 \pm 9.50 \mathrm{nmol} / \mathrm{min} / \mathrm{ml}(\mathrm{n}=63)$ and ranged from 2.73 to $274.26 \mathrm{nmol} / \mathrm{min} / \mathrm{ml}$. This activity did not differ from PON1 paraoxonase activity $(93.83 \pm 14.38$ $\mathrm{nmol} / \mathrm{min} / \mathrm{ml}$ ) determined in 30 adults with a mean age of 41.3 years (unpublished results).

As shown in Table 3, serum PON1 activity towards paraoxon was inversely related to atherogenic index (total cholesterol/HDL ratio) $(\mathrm{p}=0.027)$. No further associations with other lipid parameters were observed.

Antioxidant ability of the serum was expressed in Trolox equivalents, exhibiting the same antioxidant ability as the sample. Mean antioxidant capacity (TEAC) in the serum of children between the age of 11 and 12 years, was $1.64 \pm 0.07 \mathrm{mmol} / \mathrm{l}(\mathrm{n}=63)$ with the range from 0.71 to $3.35 \mathrm{mmol} / \mathrm{l}$.

Logistic regression was used to determine whether the measurements of BMI or TAG are related to the presence of TEAC deficiency, i.e. whether BMI, TAG and some other measures are predictive of having decreased serum total antioxidant defense. BMI and TAG (Fig. 1) were found to be significant risk factors for total antioxidant deficiency $(\mathrm{p}=0.019$ and $\mathrm{p}=0.008$, respectively). Odds ratio for BMI was 1.14 (95\% CI: 1.02-1.27) and for TAG 4.97 (95\% CI: 1.51-16.33).

No significant correlations were found between TEAC and the parameters of lipid metabolism such as total cholesterol $(\mathrm{r}=-0.070, \mathrm{p}=0.584, \mathrm{n}=63)$, LDLcholesterol $(\mathrm{r}=-0.010, \mathrm{p}=0.936, \mathrm{n}=63) \quad$ or HDLcholesterol $(\mathrm{r}=0.213, \mathrm{p}=0.107, \mathrm{n}=58)$ that were expressed by the Pearson's product moment and Spearman's correlation coefficients.

Figure 2 shows that girls had significantly higher serum PON1 arylesterase activity $(85.84 \pm 3.65 \mu \mathrm{mol} / \mathrm{min} /$ $\mathrm{ml} ; \mathrm{n}=27)$ than boys $(77.31 \pm 2.32 \mu \mathrm{mol} / \mathrm{min} / \mathrm{ml} ; \mathrm{n}=36$, $\mathrm{p}=0.044$ ). PON1 paraoxonase activity in 27 girls was $112.92 \pm 15.96 \mathrm{nmol} / \mathrm{min} / \mathrm{ml}$, while in 36 boys it was 
Table 1. Characteristics of studied subjects

\begin{tabular}{lll}
\hline Parameter & Mean \pm SEM (n) & R. V. \\
\hline Gender $(M / F)$ & $29 / 41(70)$ & \\
Age & $11.63 \pm 0.06(70)$ & \\
& $(11-12)$ & \\
BMI $\left(\mathrm{kg} / \mathrm{m}^{2}\right)$ & $19.85 \pm 0.60(69)$ & $<4.5$ \\
Serum cholesterol & & $<1.42$ for boys \\
Total & $4.11 \pm 0.07(70)$ & $<1.68$ for girls \\
HDL & $1.35 \pm 0.04(65)$ & $<3.4$ \\
& & $<1.3$ \\
LDL & $2.54 \pm 0.07(70)$ & \\
Triacylglycerols $(\mathrm{mmol} / \mathrm{l})$ & $0.98 \pm 0.08(69)$ & \\
AI & $3.21 \pm 0.10(65)$ & \\
\hline
\end{tabular}

AI (atherogenic index) means total cholesterol/HDL cholesterol; $\mathrm{n}$ means the number of subjects in our study group. R. V. means reference values for children determined in our laboratory

Table 2. PON1 arylesterase activity and its relationship to parameters of lipid profile of children.

\begin{tabular}{llll}
\hline & $\mathbf{r}$ & $\mathbf{n}$ & Significance level (p) \\
\hline Cholesterol & & & \\
Total & 0.130 & 63 & 0.309 \\
$H D L$ & 0.189 & 58 & 0.153 \\
LDL & -0.040 & 63 & 0.756 \\
Triacylglycerols & 0.038 & 62 & 0.767 \\
AI & -0.131 & 58 & 0.325 \\
\hline
\end{tabular}

AI (atherogenic index) means total cholesterol/HDL-cholesterol; $n$ means the number of subjects in our study group.

Table 3. PON1 paraoxonase activity and its relationship to parameters of lipid profile of children

\begin{tabular}{lrll}
\hline & $\mathbf{r}$ & $\mathbf{n}$ & Significance level (p) \\
\hline Cholesterol & & & \\
Total & -0.116 & 63 & 0.364 \\
HDL & 0.126 & 58 & 0.344 \\
LDL & -0.204 & 63 & 0.109 \\
Triacylglycerols & -0.147 & 62 & 0.253 \\
AI & -0.290 & 58 & $0.027^{*}$ \\
\hline
\end{tabular}

* $\mathrm{P}<0.05, \mathrm{AI}$ (atherogenic index) means total cholesterol/HDL-cholesterol; $\mathrm{n}$ means the number of subjects in study group.

lower by $24 \%(86.02 \pm 11.35 \mathrm{nmol} / \mathrm{min} / \mathrm{ml})$ but this difference did not reach the level of significance $(\mathrm{p}=0.227)$.

Moreover, no significant difference was observed in the concentration of circulating HDL- cholesterol between both gender groups (girls: $1.31 \pm 0.05$ $\mathrm{mmol} / \mathrm{l}, \mathrm{n}=28$ and boys: $1.36 \pm 0.05 \mathrm{mmol} / \mathrm{l}, \mathrm{n}=37$; $\mathrm{p}=0.542$ ). The levels of total and LDL-cholesterol were also not different between both gender groups (girls $4.16 \pm 0.12 \mathrm{mmol} / \mathrm{l}, \mathrm{n}=29$ vs. boys $4.08 \pm 0.10 \mathrm{mmol} / \mathrm{l}$, 


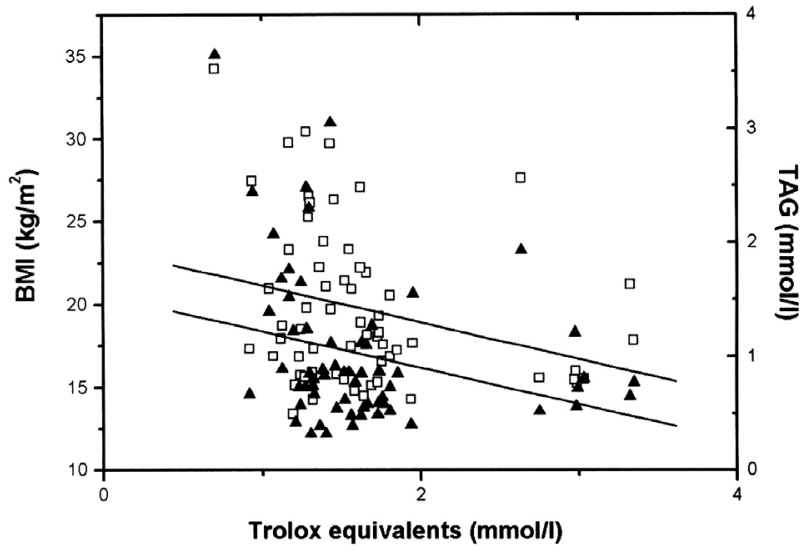

Fig. 1. Associations between serum antioxidant capacity quantified by the TEAC assay as Trolox equivalents and BMI ( $\square$, $\mathrm{p}=0.019, \mathrm{n}=62)$ or TAG $(\Delta, \mathrm{p}=0.008, \mathrm{n}=62)$ in healthy children.

$\mathrm{n}=41, \mathrm{p}=0.619$ for total cholesterol and for LDL: girls $2.57 \pm 0.11 \mathrm{mmol} / \mathrm{l}, \mathrm{n}=29$ vs. boys $2.51 \pm 0.08 \mathrm{mmol} / \mathrm{l}$, $\mathrm{n}=41 ; \mathrm{p}=0.596)$.

Regarding the gender, no significant differences were observed in TAG $(1.09 \pm 0.14 \mathrm{mmol} / \mathrm{l}, \mathrm{n}=29$ in girls vs. $0.91 \pm 0.09 \mathrm{mmol} / \mathrm{l}, \mathrm{n}=40$ in boys; $\mathrm{p}=0.366)$ and in atherogenic index (girls: $3.32 \pm 0.19, \mathrm{n}=28$ vs. boys: $3.14 \pm 0.11, \mathrm{n}=37 ; \mathrm{p}=0.688)$.

The antioxidant capacity of serum was similar in both gender groups $(1.59 \pm 0.08 \mathrm{mmol} / \mathrm{l}, \mathrm{n}=36$ for boys and $1.68 \pm 0.13 \mathrm{mmol} / \mathrm{l}, \mathrm{n}=27$ for girls; $\mathrm{p}=0.807$ ).

\section{Discussion}

It is generally accepted that high total cholesterol level is linked with a greater risk for development of coronary artery disease and other organ complications. Taking into account all recent studies it has been shown that every fourth child in Slovakia aged 11 to 12 years has increased cholesterol levels (above $4.5 \mathrm{mmol} / \mathrm{l}$ ) (Nagyová 2004). We can confirm this assertion because we found that 17 children out of 70 participants had total cholesterol over $4.5 \mathrm{mmol} / \mathrm{l}$.

PON1 activity has already been determined in children suffering from chronic renal failure (Ece et al. 2005) or bronchial asthma exacerbation (Gornicka et al. 2002) and it was found to be decreased in comparison to the controls. In this study, we determined PON1 activity as well as its association with lipid parameters in healthy children between the age of 11 and 12 years. We found that PON1 activities in children were very similar to corresponding PON1 activities in adults. This finding is in accordance with the assertion that adult PON1 levels

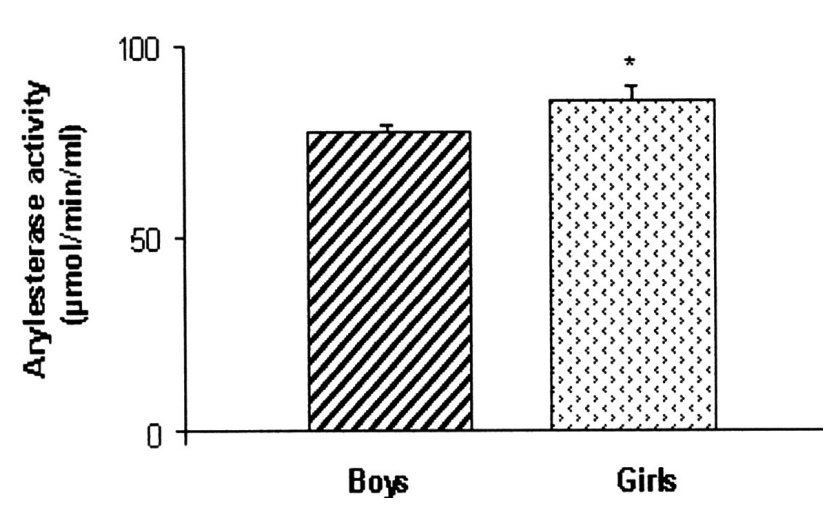

Fig. 2. PON1 arylesterase activity $(\mu \mathrm{mol} / \mathrm{min} / \mathrm{ml})$ determined in children ( 27 girls and 36 boys), $* p=0.044$.

are reached approximately 1 year after birth (Mackness et al. 1998) and then they tend to stay constant until menopause in women or middle aged men.

Our data showed no relationship between PON1 arylesterase activity and HDL or other parameters of lipid metabolism. Similarly, PON1 activity towards paraoxon was not related to cholesterol-associated parameters such as total-, LDL- or HDL-cholesterol. The only observed relationship was that with atherogenic index which is usually used for predicting of coronary artery disease in humans.

According to our findings, boys had significantly lower PON1 arylesterase activity than girls. This finding is in accordance with our previous results reported in adults, whose PON1 arylesterase activity was also marginally affected by gender $(\mathrm{p}=0.056)$ (unpublished results). Our findings are controversial to the results of Tomás et al. (2000) who found that PON1 arylesterase activity in normocholesterolemic subjects was unaffected by gender. Therefore, further studies are needed.

As expected, PON1 paraoxonase activity in children was not affected by gender. Our results did not also show any significant differences in individual parameters of lipid profile or the antioxidant capacity between both gender groups.

It is alarming that about $25 \%$ children randomly selected for this study had increased total cholesterol levels $(>4.5 \mathrm{mmol} / \mathrm{l})$, which indicated a higher risk of heart disease or heart attacks in adult age. Moreover, we have determined activity of the PON1 enzyme, another marker or predictor of possible atherosclerotic changes, in blood vessels in 11- and 12-year-old children. We have found that their PON1 activity was very similar to PON1 activity in adults.

Interesting observations of our study concern correlations between total serum antioxidant capacity and 
BMI or TAG (Fig. 1). Our findings imply that BMI is a risk factor for the decrease in total antioxidant ability of the organism when determined by the TEAC method. It was found with $95 \%$ confidence that for every additional unit of BMI (measured in $\mathrm{kg} / \mathrm{m}^{2}$ ) increases the risk of decrease of total antioxidant capacity in children below the norm by 1.14 times. From this point of view, the decrease of body mass could contribute to the reduction of damaging oxidative processes in the organism and thus it can be an important factor in preventing the development of diseases in which oxidative stress plays a role.

Furthermore, high body mass index (overweight) in children is associated with a decrease of total serum antioxidant defense. The decrease in serum antioxidants could be linked to elevated production of oxidatively modified molecules and could therefore cause a greater risk for increased oxidative stress and for heart and vascular diseases such as atherosclerosis.

\section{Acknowledgements}

This work was supported by VEGA grant of Ministry of Education of SR 1/1157/04 and 1/3037/06, APVV grant 51-027, grant of Comenius University UK/28/2004 and Mind\&Health-civil association. Authors wish to thank Dr. Bianca Fuhrman from Lipid Research Laboratory, Technion Faculty of Medicine and Rambam Medical Center, Haifa, Israel for her useful comments and help with introduction of the PON1 method.

\begin{abstract}
Abbreviations:
AI, atherogenic index; BMI, body mass index; HDL, high-density lipoprotein; LDL, low-density lipoprotein; PON1, paraoxonase1; TAG, triacylglycerols; OR, odds ratio
\end{abstract}

\section{References}

AHMED Z, RAVANDI A, MAGUIRE GF, EMILI A, DRAGANOV DI, LA DU BN, KUKSIS A, CONNELLY PW: Apolipoprotein A-I promotes the formation of phosphatidylcholine core aldehydes that are hydrolyzed by paraoxonase (PON-1) during high density lipoprotein oxidation with a peroxynitrite donor. J Biol Chem 276: 24473-24481, 2001.

AVIRAM M, HARDAK E, VAYA J, MAHMOOD S, MILO S, HOFFMAN A, BILLICKE S, DRAGANOV D, ROSENBLAT M: Human serum paraoxonase (PON) Q and R selectively decrease lipid peroxides in human coronary and carotid atherosclerotic lesions: PON1 esterase and peroxidase-like activities. Circulation 101: 2510-2517, 2000.

AVIRAM M, ROSENBLAT M: Paraoxonase 1, 2, and 3, oxidative stress, and macrophage foam cell formation during atherosclerosis development. Free Radic Biol Med 37: 1304-1316, 2004.

BELTOWSKI J, WÓJCICKA G, MARCINIAK A: Species- and substrate-specific stimulation of human plasma paraoxonase 1 (PON1) activity by high chloride concentration. Acta Biochem Polon 49: 927-936, 2002.

ECE A, ATAMER Y, GURKAN F, DAVUTOGLU M, BILICI M, TUTANC M, GUNES A: Paraoxonase, anti-oxidant response and oxidative stress in children with chronic renal failure. Pediatr Nephrol 27: 1279-1284, 2005.

FRIEDEWALD WT, LEVY RI, FREDERICKSON DS: Estimation of the concentration of low-density lipoprotein cholesterol in plasma without use of the preparative ultracentrifuge. Clin Chem 18: 449-502, 1972.

FUHRMAN B, VOLKOVA N, AVIRAM M: Paraoxonase 1 (PON1) is present in postprandial chylomicrons. Atherosclerosis 180: 55-61, 2005.

GAN KN, SMOLEN A, ECKERSON HW and LA DU BN: Purification of human serum paraoxonase/arylesterase. Evidence for one esterase catalyzing both activities. Drug Metab Dispos 19: 100-106, 1991.

GORNICKA G, BELTOWSKI J, WOJCICKA G, JAMROZ A: Serum paraoxonase activity, total antioxidant potential and lipid peroxidation products in children with bronchial asthma exacerbation. Wiad Lek 55: 257-263, 2002.

JAMES RW, DEAKIN SP: The importance of high-density lipoproteins for paraoxonase-1 secretion, stability and activity. Free Radic Biol Med 37: 1986-1994, 2004.

MACKNESS B, DURRINGTON PN, MACKNESS MI: Human serum paraoxoanse. Gen Pharmacol 3: 329-336, 1998.

MACKNESS B, MACKNESS MI, DURRINGTON PN, ARROL S, EVANS AE, MCMASTER D, FERRIÈRES J, RUIDAVETS JB, WILLIAMS NR, HOWARD AN: Paraoxonase activity in two healthy populations with differing rates of coronary heart disease. Eur J Clin Invest 30: 4-10, 2000. 
MACKNESS MI, HARTY D, BHATNAGAR D, WINOCOUR PH, ARROL S, ISHOLA M, DURRINGTON PN: Serum paraoxonase activity in familial hypercholesterolemia and insulin-dependent diabetes mellitus. Atherosclerosis 86: 193-199, 2001.

MACKNESS B, DURRINGTON PN, BOULTON AJM, HINE D, MACKNESS MI: Serum paraoxonase activity in patients with type I diabetes compared to healthy controls. Eur J Clin Invest 32: 259-264, 2002a.

MACKNESS MI, MACKNESS BM, DURRINGTON PN: Paraoxonase and coronary heart disease. Atheroscler Suppl 3 (4): 49-55, 2002b.

NAGYOVÁ Z: Cholesterol - is it necessary to monitor in children? (in Slovak) Child 26, 2004.

RE R, PELleGRINI N, PROTEGGENTE A, PANNAlA A, YANG M, RICE-EVANS C: Antioxidant activity applying an improved ABTS radical cation decolorization assay. Free Radic Biol Med 26: 1231-1237, 1999.

SHIH DM, XIA YR, MILLER E, CATELLIANI LW, SUBBANAGOUNDER G, CHEROUTRE H, FAULL KF, BERLINER JA, WITZTUM JL, LUSIS AJ: Combined serum paraoxonase knockout/apolipoprotein E knockout mice exhibit increased lipoprotein oxidation and atherosclerosis. J Biol Chem 275: 17527-17535, 2000.

TOMÁS M, SENTÍ M, GARCÍA-FARIA F, VILA J, TORRENTS A, COVAS M, MARRUGAT J: Effect of simvastatin therapy on paraoxonase activity and related lipoproteins in familial hypercholesterolemic patients. Arterioscler Thromb Vasc Biol 20: 2113-2119, 2000.

\section{Corresponding author}

Duračková Zdeňka, Department of Medical Chemistry, Biochemistry and Clinical Biochemistry, Faculty of Medicine, Comenius University, Sasinkova 2, 81372 Bratislava, Slovakia. E-mail: zdenka.durackova@fmed.uniba.sk 